\title{
Analysis of the Training Objectives and Paths of Applied Talents in International Trade Major
}

\author{
Wang Wei, Zhao Guiyan*,Wu Xiaohua,Dong Dapeng,Bian Jilan \\ College of Economics and Management, Heilongjiang Bayi Agricultural University, Daqing \\ 163319, China \\ *corresponding author
}

Keywords: International trade major; International trade; applied talents training path

\begin{abstract}
The application-oriented talents training should be investigated among graduates in colleges and universities. From the aspects of target, curriculum setting, teaching methods, school enterprise cooperation, etc., this paper analyzes the orientation through sorting out the empirical analysis of the survey data of graduates of international trade major, and provides targeted suggestions for the application-oriented personnel training of international trade major according to the analysis results.
\end{abstract}

\section{Preface}

The training of applied talents focuses on the word "application". It requires that the concept of talents, the concept of quality and the concept of education that reflect the spirit of the times and the requirements of social development should be taken as the guide, the teaching content and links should be updated, the teaching methods and means should be changed, the teaching level should be comprehensively improved, and the high-quality applied talents with strong social adaptability and competitiveness should be cultivated[1-2].

In developed countries, there are abundant research results on the training mode of applied undergraduate talents. Japan's application-oriented undergraduate education attaches great importance to the cultivation of guiding technical talents that can directly serve the society, and the cultivation of undergraduate talents with innovation ability and strong practical ability to adapt to social development guided by market demand. (Akira Arimoto, 1997; Masaaki Ogasawara, 2002). Comparatively speaking, the research of Applied Undergraduate Talent Training Mode started late in China, mainly including the research of training objectives, curriculum content, practical teaching, school enterprise cooperation, combination of production, teaching and research, "double teacher" teachers, evaluation mechanism and other specific contents[3]. Chen Yi (2009) summarized the talent training mode as "six modernizations", that is, "professional orientation of marketization, applied curriculum, modular teaching content, project-based teaching practice, diversified production and learning cooperation, and full process employment guidance." Lei Liang and Peng Jun (2009) proposed and explored the "3 + 1" talent training model. Sun Cheng (2013) summarized seven application-oriented personnel training modes: embedded, segmented, pre-employment, project driven, entrepreneurial park, internship base and order mode. Zhang (2015) believed that the application-oriented talent training system with Chinese characteristics could be 
constructed through classified development, transformation development and differential development among colleges and universities[4].

It mainly introduces the specific practice of colleges and universities, as well as the resulting ideas for the reform of talent training mode, which has certain enlightenment. Hu Jian (2005) introduced a series of measures taken by Xi'an University of Finance and economics to cultivate application-oriented high-level specialized talents, such as "implementing the compound training mode of combining platform and module, carrying out the" $2+2$ "teaching reform, constructing the curriculum system of application-oriented talents training, and constructing a reasonable practical teaching system", and put forward three points to further innovate the design of application-oriented talents training mode The first is to further strengthen the construction of majors and actively explore the reform of credit system. The second is to highlight the important position of practical teaching links, build and improve the practical teaching system. The third is to strengthen the construction of experimental teachers[5]. Chen Jiejing (2013) pointed out that the determination of the training objectives of German University of applied technology is guided by the job needs of students in the future, and their graduates should be more close to the actual needs of the employing enterprises. There are two characteristics of the training mode of German University of Applied Technology: one is to set up majors according to the needs of enterprises; the other is to highlight practical teaching.

To sum up, at present, there is no unified and clear understanding of the connotation, characteristics and training mode of applied talents. Therefore, it is necessary to learn from the successful experience of domestic and foreign applied talents training, strengthen the theoretical research on the training mode of applied talents, and have a clear understanding of its related concepts Urgent affairs. By learning from the successful experience at home and abroad, this study explores the training mode of applied talents, in order to guide the current education practice.

\section{A Survey of the Current Situation of Graduates Majoring In International Trade}

\section{1 introduction to the questionnaire}

This study mainly uses the method of questionnaire to investigate the specific situation of the cultivation of international trade professionals in universities.

\section{2 questionnaire distribution and collection}

The students in this survey include those who have graduated from the international trade major and those who intend to graduate. Through the distribution and promotion on QQ and wechat platforms, 292 valid questionnaires have been collected, no invalid questionnaires, and the results of the questionnaires can be directly counted by using the questionnaire stars.

\subsection{Analysis of investigation results}

\subsubsection{Analysis of training objectives of international trade}

Through the analysis of the results of the questionnaire, as shown in Figure 1: 86.3\% of the training objectives of the international trade major are application-oriented talents, indicating that the training objectives of the international trade major in most undergraduate colleges are application-oriented talents, and the training talents are application-oriented talents. 


\begin{tabular}{|c|c|c|}
\hline option & Subtotal & Proportion \\
\hline Controller & 32 & $10.96 \%$ \\
\hline practical personnel & 252 & $86.3 \%$ \\
\hline research-type professionals & 8 & $2.74 \%$ \\
\hline Person times of this question & 292 & \\
\hline
\end{tabular}

Figure 1 training objectives of international trade

\subsubsection{Analysis of knowledge and ability structure of international trade professionals}

Through the analysis of the questionnaire results, as shown in Figure 2: $86.3 \%$ of the application-oriented talents are oriented to practice in the knowledge and ability structure of international trade professionals, indicating that most of the talents trained by international trade majors in undergraduate colleges are application-oriented talents mainly based on practice.

\begin{tabular}{|c|c|c|}
\hline option & Subtotal & Proportion \\
\hline Theoretical researcher & 8 & $2.74 \%$ \\
\hline Senior professional talents with theory as the main body & 32 & $10.96 \%$ \\
\hline Practical talents & 252 & $86.3 \%$ \\
\hline Person times of this question & 292 & \\
\hline
\end{tabular}

Figure 2 Positioning of knowledge and ability structure of international trade professionals

\subsubsection{Analysis of the nature of the work unit of graduates majoring in international trade}

According to the analysis of the questionnaire results, as shown in Figure 3, 32.88\% of the graduates of international trade major work in foreign trade enterprises, and $49.32 \%$ of them have no requirements for the nature of enterprises, which shows that the graduates of international trade major have established a correct outlook on career selection and pay more attention to the application of their knowledge to practical work.

\begin{tabular}{|c|c|c|c|}
\hline option & Subtotal & Proportion & \\
\hline Government economic management department & 24 & a & $8.22 \%$ \\
\hline Teaching and research institutions & 12 & 1 & $4.11 \%$ \\
\hline foreign trade enterprise & 96 & & $32.88 \%$ \\
\hline Financial institution & 16 & 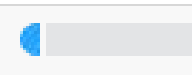 & $5.48 \%$ \\
\hline Above all & 144 & - & $49.32 \%$ \\
\hline Person times of this question & 292 & & \\
\hline
\end{tabular}

Figure 3 nature of work units of graduates majoring in international trade

\subsubsection{Analysis of teaching methods adopted by international trade teachers}

Through the analysis of the results of the questionnaire, case teaching and pure theory teaching accounted for $53.42 \%$ and $52.05 \%$ respectively in the graduate colleges of international trade majors, and the highest proportion of teaching methods that were beneficial to the cultivation of 
international economic and trade talents was school enterprise cooperation, which reached 84.93\%, indicating the talent cultivation of the undergraduate colleges in the future In the reform of the training mode, we should increase the school enterprise cooperation courses, comprehensively promote the school enterprise cooperation education, and build a new application-oriented talent training mode; most graduates of international trade major think that the practical effect of the combination of theory and practice teaching in the graduated universities is general, accounting for 49.32\%.

\section{The Way of Training Applied Talents in International Trade}

\subsection{Promote students' practical ability through competition}

In the training process of application-oriented undergraduate talents, it is very important for the cultivation of students' initiative and creative thinking ability. The international trade specialty promotes the improvement of students' practical ability by organizing students to participate in national competitions such as cross-border e-commerce competition, foreign trade document post skill competition, etc. Through participating in professional competitions, students have mobilized their subjective initiative, developed innovative thinking, and stimulated their independent learning. In order to improve the practical ability of students majoring in international trade, each school has provided a good learning platform for students to carry out competition training through opening professional laboratories. At the same time, in order to cultivate college students' awareness of innovation and entrepreneurship and team cooperation, we should take the implementation of national, provincial and university level innovation and entrepreneurship training programs as an opportunity to build the implementation system of national, provincial and university level innovation and entrepreneurship training programs, so as to provide strong guarantee for college students to participate in innovation and entrepreneurship activities.

\subsection{Industry university research cooperation}

The application-oriented colleges and universities should combine the characteristics of geographical location and service area, and give full play to their distinctive characteristics in school running orientation, personnel training methods and specifications. There are great differences with the traditional academic universities, but also with higher vocational colleges in students' ability requirements, teaching quality evaluation system, degree awarding and other aspects. In order to survive and develop sustainably, the undergraduate colleges and universities must be reoriented and compete with other types of colleges and universities. On the basis of the original school characteristics and traditions, the applied talents training mode should be rebuilt to meet the needs of regional economic and social development for technical talents.

Make clear the orientation of running a university. We will explore cooperation between the University and the government, between the University and the enterprise, highlight the characteristics of application-oriented undergraduate education, and strengthen the construction of the teaching staff, the reform of personnel training programs, and the renewal of the curriculum system. Cultivate applied talents that meet the needs of industry, industry and regional economic development. We will focus on strengthening the construction of experimental training environment, practice base and virtual simulation platform in application-oriented universities, encourage the participation of industry enterprises, deepen the integration of production, teaching and research, and build experimental training and practice facilities that integrate production, learning and research. We will effectively transform talent cultivation into the integration of industry and 
education, school enterprise cooperation, and the cultivation of application-oriented talents, so as to truly realize the social development of serving the local economy.

\subsection{Establish excellent practical teachers' culltivation system}

Teachers' practical teaching ability directly affects the effect of practical teaching. Teachers who are proficient in trade operation, solid theoretical basis and good communication ability are important factors that affect the effect of students' practical teaching. Therefore, the application-oriented undergraduate colleges need to establish an excellent practical teaching team, adopt the method of internal training and external introduction, establish a stable "double teacher" teaching team, improve teachers' incentive and assessment methods, encourage teachers' enthusiasm for practical teaching, urge teachers to improve practical teaching and professional operation ability, promote the development of practical teaching, and cultivate strong practical operation ability Application talents with ability.

\section{Acknowledgement}

The paper was supported by Heilongjiang Bayi Agricultural University audit and evaluation project (Based on the needs of enterprises, research on the training mode of composite application talents of international trade major).

\section{References}

[1] Cindy Coe. Amy Zehnder. Dennis Kinlaw. Coaching for Commitment: Achieving Superior Performance from Individuals and Teams (Third Edition).2008.

[2] Zhao Guiyan, Bian Jilan, Dong dabeng. Study on application-oriented personnel training mode of international trade based on KSAO model. Foreign trade and economic cooperation, 2013, (11): 147-148

[3] Gu Yong'an. On the transformation and development of New Undergraduate Institutions. Beijing: China Social Sciences Press, 2012:5-30

[4] Qin Yueyue. Research and practice of Application-oriented Undergraduate Training Mode in Colleges and universities. Chongqing University, 2009

[5] Pan Maoyuan. Theory and practice of Applied Talents Training. Xiamen: Xiamen University Press, 2011:10-25 